\title{
KONSTRUKSI DAN ARAH BARU PEMAHAMAN TERHADAP I'JAZ AL-QURAN
}

\author{
Fathul Mu'in \\ Universitas Islam Negeri Raden Intan Lampung \\ Email: fathulmuin@radenintan.ac.id \\ Rudi Santoso \\ Universitas Islam Negeri Raden Intan Lampung \\ Email: rudisantoso@radenintan.ac.id
}

\begin{abstract}
I'jaz is the ability to subdue and show it self above all others. when this term is pinned to the qur'an, it demands that the holy book brought by the Prophet Muhammad be able to subdue all the writings that have ever existed, while converting the qur'an into the most noble and undisputed book. The miracles of the qur'an cannot be matched. This is manifested in the aspect of the beauty of language, the stories contained in it, in addition to monotheism, the rules of the Shari'a, and others, as well as extraordinary complete scientific information when examined in depth. To appreciate the miracle of this Qur'an, every Muslim should fulfill the right of the Qur'an by reading and memorizing it, analyzing it and applying it in daily life as a guide for those who believe and devout.
\end{abstract}

Keyword: I'jaz, the Miracle, the Holy Qur'an

\begin{abstract}
Abstrak
I'jaz merupakan kemampuan untuk menundukkan dan menunjukkan dirinya melebihi yang lainnya. Ketika istilah ini disematkan kepada Alquran, maka kitab suci yang dibawa oleh Rasulullah ini dapat menundukkan seluruh tulisan-tulisan yang pernah ada, sekaligus juga menobatkan Alquran menjadi mu'jizat sekaligus kitab paling mulia dan tidak terbantahkan. Kemukjizatan Al-Qur'an tidak mungkin bisa tertandingi. Hal ini terwujud dalam aspek keindahan bahasa, kisah yang terkandung di dalamnya, selain tauhid, aturan syariat, dan sebagainya, serta informasi ilmiah yang luar biasa lengkapnya jika ditelaah secara mendalam. Untuk mengapresiasi kemukjizatan Alquran ini, hendaknya setiap umat Islam memenuhi hak Alquran yaitu dengan membaca, menghafal, mengkaji, menganalisa serta diaplikasikan dalam kehidupan sehari-hari sebagai petunjuk bagi orang yang bertakwa.
\end{abstract}

Kata Kunci : I'jaz, Mu'jizat, Al-Qur'an

\section{A. Pendahuluan}

Al-Qur'an adalah mukjizat Islam yang kekal dan mukjizatnya diperkuat oleh kemajuan ilmu pengetahuan. Allah menurunkan Al-Qur'an secara berangsur-angsur selama kurang lebih 23 tahun. Berbeda dengan kitab-kitab suci yang diturunkan kepada paraRasul sebelum Nabi Muhammad SAW. Seperti Nabi Ibrahim AS yang diberi shuhuf (lembaran-lembaran suci) dalam satu waktu alias sekaligus. Demikian pula dengan Nabi Musa aAS dan Nabi Isa AS yang menerima al-alwâh(lembaran-lembaran suci) yang di dalamnya terdapat teks-teks Taurat dalam satu waktu.Nabi Isa AS juga menerima kitab suci Injil sekaligus. 
Sedangkan kepada Nabi Muhammad SAW, Allah SWTmenurunkannya dengan sebuah proses yang cukup panjang. Di balik hal itu, tentu terdapat hikmahhikmah ilahiyah, sebagaimana diisyaratkan dalam berbagai ayat Al-Qur'an. ${ }^{1}$

$\mathrm{Mu}^{\prime}$ jizat yang diperlihatkan oleh seorang Rasul, merupakan sesuatu yangdari sebelumnya telah diketahui oleh manusia secara umum. Dapat dikatakan jugasesuatu yang dapat dipahami oleh manusia akan tetapi tidak dapat dilakukan ataudiperoleh oleh manusia awam. Maka mu'jizat bukanlah sesuatu yang sangat barudan tidak dapat dipahami oleh siapa pun. Mu'jizat merupakan hal yang menyalahi sesuatu yang biasanya terjadi akan tetapi masih dalam batas pengetahuan yangdapat dipahami manusia, sehingga dapat dibukitkan dan disaksikan oleh manusiapada umumnya. Karena apabila mu'jizat bukan sesuatu yang dapat dimengerti maka tidak akan memberikan manfaat bagi umat yang diperlihatkan mu'jizat tersebut. Akan tetapi kalau dapat dipahami dan ia menyadari kekerdilan dirinya dihadapan mu'jizat tersebut sehingga tergerak untuk mengimaninya secara objektif. ${ }^{2}$

Al-Qur'an yang secara harfiah berarti bacaan sempurnamerupakan suatu nama pilihan Allah yang sungguh tepat, karena tiada satu bacaan pun sejak manusia mengenal tulis baca lima ribu tahun yang lalu yang dapat menandingi Al-Qur'an Al-Karim, bacaan sempurna lagi mulia itu. Tiada bacaan semacam AlQur'an yang dibaca oleh ratusan juta orang yang tidak mengerti artinya dan atau tidak dapat menulis dengan aksaranya. Bahkan dihafal huruf demi huruf oleh orang dewasa, remaja, dan anak-anak. Tiada bacaan melebihi Al-Qur'an dalam perhatian yang diperolehnya, bukan saja sejarahnya secara umum, tetapi ayatdemi ayat, baik dari segi masa, musim, dan saat turunnya, sampai kepadasebab-sebab serta waktu-waktu turunnya. ${ }^{3}$

Al-Qur'an adalah kalam Allah yang bersifat mu'jizat yang diturunkan kepada Nabi Muhammad saw. melalui perantara Jibril dengan lafal dan maknanya dari Allah swt, yang dinukilkan secara mutawatir; membacanya merupakan ibadah; dimulai dengan surah al-Fatihah dan diakhiri dengan surah an-Nas. ${ }^{4}$ Al-Qur'an Al-Karim terdiri dari 30 juz, 114 surat dan susunannya ditentukan oleh Allah swt. Dengan cara tawqifi(berdasarkan petunjuk Alah), tidak menggunakan metode sebagimana metode-metode penyusunan buku ilmiah. Buku ilmiah yang membahas satu masalah selalu menggunakan satu metode tertentu, metode ini tidak terdapat dalam Al-Qur'an Al-Karim, yang di dalamnya banyak persoalan induk silih berganti diterangkan. ${ }^{5}$

Al-Qur`an sebagai kitab samawi terakhir yang diberikan kepada Nabi Muhammad saw. sebagai penuntun dalam rangka pembinaan umatnya

\footnotetext{
1 Abdul Shabur Syahin, Saat Al-Qur'an Butuh Pembelaan (Jakarta: Erlangga, 2014), h. 11.

2 Az-Zarqani, Muhammad, Manahil al-Irfan fi Ulum al-Alquran, Jilid. 1,tahqiq: Fawwaz Ahmad Zamarli, (Beirut: Dar al-Kutub al-Arabi, 1415 H/1995 M), h. 63.

${ }^{3}$ M. Quraish Shihab, Wawasan AL-Qur'an (Bandung: Mizan, 1996), h. 3.

4 M. Quraish Shihab, et. all., Sejarah dan Ulum Al-Qur"an, (Jakarta: Pusataka Firdaus, 2008), h. 1 .

5 Ibid, h. 14 .
} 
sangatlah fenomenal. Lantaran di dalamnya sarat nilai-nilai yang unik, pelik dan rumit sekaligus luar biasa. Hal ini lebih disebabkan karena eksistensinya yang tidak hanya sebagai ajaran keagamaan saja, melainkan ajaran kehidupan yang mencakup total tata nilai semenjak hulu peradaban umat manusia hingga hilirnya. Diantara nilai-nilai tersebut adalah pada aspek kebahasaannya, isyaratisyarat ilmiah dan muatan hukum yang terkandung didalamnya. Saking pelik, unik, rumit dan keluar biasanya tak pelak ia menjadi objek kajian dari berbagai macam sudutnya, yang darinya melahirkan ketakkjuban bagi yang beriman dan cercaan bagi yang ingkar.

Namun demikian, seiring dengan waktu dan kemajuan intelkstualitas manusia yang diikuti dengan perkembangan ilmu pengetahuan modern, sedikit demi sedikit nilai-nilai tersebut dapat terkuak dan berpengaruh terhadap kesadaran manusia akan keterbatasan dirinya, sebaliknya mengokohkan posisi Al-Qur`an sebagai kalam Tuhan yang kudus yang berfungsi sebagai petunjuk dan bukti terhadap kebenaran risalah yang dibawa Nabi Muhammad saw. Serentetan nilai Al-Qur'an yang unik, pelik, rumit sekaligus luar biasa hingga dapat menundukkan manusia dengan segala potensinya itulah yang lazimnya disebut dengan mukjizat. Makalah ini ditulis untuk mengetahui mu'jizat yang terkandung dalam kitab suci umat Islam yang bernama Al-Qur'an.

\section{B. Pembahasan}

\section{Pengertian Mukjizat}

Secara bahasa, kata I'jaz berasal dari kata 'ajz yang berartikelemahan atau ketidak rnarnpuan. Kata I'jaz adalah bentuk nominaverbal dati kata 'ajaza yang berarti mendahului. Dengan dernikianistilah al-l'jaz al-Tmi (kemukjizatan ilmiah) Alquran atau al-Hadismisalnya mengandung makna bahwa kedua sumber ajaran agama itutelah mengabarkan kepada kita tentang fakta-fakta ilmiah yang kelakditernukan dan dibuktikan oleh eksperiment sains umat manusia, danterbukti tidak dapat dicapai atau diketahui dengan sarana kehidupanyang ada pada zaman Rasulallah saw. Hal itu membuktikan kebenaranyang disampaikan oleh Rasulallah saw. ${ }^{6}$

Kata i'jaz atau mukjizat memang tidak disebutkan dalam Al-Qur'an maupun oleh para penulis terdahulu. Sebaliknya, mereka menggunakan katakata Ayah atau Karamah, sampai Al-Wasithi memilih i'jazul-Qur'an sebagai judul tulisan beliau yang terkenal. Kata $M u^{\prime} j i z a h$ memberi makna baru yang didefinisikan oleh para teolog sebagai sesuatu yang di luar nalar atau kemampuan akal manusia, menantang dan tidak mungkin dikalahkan.7Kata mukjizat diambil dari bahasa Arab أعجزa'jaza-i'jazyang mengandungarti

6 Ahmad Fuad Pasya, Dimensi Sains AI-Qur'an, cet.I, (Solo: PT. TigaSerangkai Pustaka Mandiri, 2004), h. 23.

7 Yusuf Al-Hajj Ahmad, Mukjizat Al-Qur'an yang Tak Terbantahkan (Solo: Aqwam, 2016), h. 39. 
ketidakmampuan. ${ }^{8}$ Mukjizat ialah membuat orang menjadi tunduk, sesuatu yang datang kemudian, dan membuat orang menjadi lemah karena tidak mempunyai kemampuan menghadapi sesuatu.

Manna al-Qattan, ahli tafsir dan fikih dari Mesir mendefinisikan mukjizat dengan sesuatu yang di luar adat kebiasaan yang tidak satu tantangan pun dapat menandinginya. Sementara itu, Abdul Karim az-Zarqani mengatakan bahwa mukjizat adalah suatu kejadian luar biasa yang dapat melemahkan manusia atau makhluk lain. Manusia tidak mampu membuat tandingan yang serupa, baik secara individu maupun kelompok. ${ }^{9} \mathrm{Ibnu}$ Khaldun dalam Muqaddimahnya berpendapat bahwa mukjizata dalah adalah perbuatan-perbuatan yang tidak dapat ditiru oleh manusia. ${ }^{10}$

Dengan redaksi yang berbeda, mukjizat didefinisikan pula sebagai sesuatu luar biasa yang diperlihatkanAllah melalui para Nabi dan Rasul-Nya, sebagai bukti atas kebenaranpengakuan kenabian dan kerasulannya. ${ }^{11}$ Sedangkan menurut M. Qurais Shihab ada empat unsur yang harus menyertai sesuatu sehingga ia dinamakan mukjizat. Keeempat unsur itu adalah:

a. Hal atau peristiwa yang luar biasa.

Yang dimaksud luar biasa adalah sesuatu yang berada diluar jangkauan sebab akibat yang diketahui secara umum hukum-hukumnya.

b. Terjadi atau dipaparkan oleh seorang yang mengaku nabi.

Apabila hal-hal yang luar biasa terjadi bukan dari seseorang yang mengaku nabi, ia tidak dinamai mukjizat.

c. Mengandung tantangan terhadap yang meragukan kenabian.

Tantangan ini harus berbarengan dengan pengakuannya sebagai nabi, bukan sebelumnya.

d. Tantangan tersebut tidak mampu atau gagal dilayani.

Bila yang ditantang berhasil melakukan hal yang serupa, maka ini berarti bahwa pengakuan sang penantang tidak terbukti. ${ }^{12}$

Manusia mengalami perkembangan dalam pemikirannya. Umat paraNabi khususnya sebelum Nabi Muhammad membutuhkan bukti kebenaran yang sesuai dengan tingkat pemikiran mereka. Bukti tersebut harus demikian jelas dan langsung terjangkau oleh indramereka. Akan tetapi, setelah manusia mulai menanjak ke tahap kedewasaan berpikir, bukti yang bersifat indrawi tidak dibutuhkan lagi. ${ }^{13}$

\footnotetext{
8 Ibn Manzur, Lisan al-Arab Jilid II, (Beirut: Dar Sodir, t.t.), h. 369.

9 Tim Penyusun, Ensiklopedi Hukum Islam Jilid 4 (Jakarta: PT. Bachtiar Baru Van Houve, 1997), h. 1223.

10 Ibnu Ahmad 'Alimi, Menyingkap Rahasia Mukjizat Al-Qur'an, (Surabaya: Mashur, 2004), h. 3 .

11 Said Agil Husain Al-Munawwar, I'jaz Al-Qur'an dan Metodologi Tafsir (Semarang: Dimas, 1994), h. 1.

12 M. Quraish Shihab, Mukjizat Al-Qur'an, Ditinjau dari Aspek Kebahasaan, Isyarat Ilmiah, dan Pemberitaan Ghaib (Bandung: Mizan, 2004), h. 36.

13 Jalaluddin As-Suyuthi, Al-Itgan fi Ulumul Qur'an, penrj. Tim Editor Indiva, Ulumul Qur'an, Studi Al-Qur'an Komprehensif Jilid 2 (Solo: Indiva Media Kreasi, 2009), h. 662.
} 


\section{Mukjizat Al-Qur'an}

Mukjizat Al-Qur'an dapat dijangkau oleh setiap orang yang menggunakan akalnyadi mana dan kapanpun. ${ }^{14}$ Bentuk lain dari $i^{\prime} j a z$ yang banyak dibicarakan, bahkan menjadi diskursus pada saat ini adalah mukjizat ilmiah dalam Al-Qur'an. Seseorang yang mempelajari secara khusus ilmu-ilmu Al-Qur'an tidak akan ragu untuk menyatakan bahwa di dalam Al-Qur'an terkandung isyarat-isyarat ilmiah, bahkan fakta-fakta ilmiah yang bersifat $i^{\prime} j a z$. Karena, hal itu melampaui batas-batas masa, umat, bahkan Nabi Muhammad sendiri sebagai penerima Al-Qur'an. ${ }^{15}$

Para ulama sepakat bahwasanya Al-Quran tidaklah melemahkan manusia untuk mendatangkan sepadan Al-Qur'an hanya karena satu aspek saja, akan tetapi karena beberapa aspek, baik aspek lafzhiyah (morfologis), ma'nawiyah (semantik) dan ruhiyah (psikologis). Semuanya bersandarkan dan bersatu, sehingga melemahkan manusia untuk melawannya. ${ }^{16}$

Walaupun telah disepakati sebagai mukjizat (bahkan mukjizat terbesar), tetapi para ulama berbeda pandangan dalam menentukan letak nilai kemukjizatan Al-Qur'an. Unsur apa yang menjadikan Al-Qur'an sebagai mukjizat masih menjadi perbincangan hingga saat ini, dan belum juga terselesaikan. Menurut Aisyah Abdurrahman (lebih dikenal sebagai Bintu Syati), seorang cendekiawan Mesir yang mendalami kajian kemukjizatan Al-Qur'an, setiap ulama yang membahas tentang kemukjizatan Al-Qur'an selalu merasa pendapatnya sebagai pendapat akhir yang paling sahih. Akan tetapi, seiring bejalannya waktu akan terbukti bahwa ulama tersebut masih meninggalkan celah kosong yang mendorong ulama setelahnya untuk mengisi kekosongan tersebut. ${ }^{17}$

Namun demikian mereka berbeda pendapat dalam meninjau segi kemukjizatan Al-Qur'an. Perbedaan itu adalah sebagai berikut:

a. Sebagian ulama berpendapat bahwa segi kemukjizatan Al-Qur'an adalah sesuatu yang terkandung dalam Al-Qur'an itu sendiri, yaitu susunan yang tersendiri dan berbeda dengan bentuk puisi orang Arab maupun bentuk prosanya, baik dalam permulaannya, maupun suku kalimatnya.

b. Sebagian yang lain berpendapat bahwa segi kemukjizatan Al-Qur'an itu terkandung dalam lafal-lafalnya yang jelas, redaksinya yang bernilai sastra dan susunannya yang indah, karena nilai sastra yang terkandung dalam Al-Qur'an itu sangat tinggi dan tidak ada bandingannya.

c. Ulama lain berpendapat bahwa kemukjizatan itu karena Al-Qur'an terhindar dari adanya pertentangan, dan mengandung arti yang lembut

14 Ibid, h. 36.

15 Yusuf Qardhawi, Al-Qur'an Berbicara tentang Akal dan Ilmu Pengetahuan (Jakarta: Gema Insani Press, 1998), h. 319.

16 Abdul Wahab Khallaf, Ilmu Ushul Figh, cet. 8, terj. Noer Iskandar al-Barsany dan Moh. Tolchah Mansoer, (Kairo: Dar al-'Ilm:1978), h. 30.

17 Aisyah Abdurrahman, Al-I'jaz Al-Bayani lil Quran, (Kairo: Darul Maarif, t.th.), h. 13. 
dan memuat hal-hal ghaib diluar kemampuan manusia dan diluar kekuasaan mereka untuk mengetahuinya.

d. Ada lagi ulama yang berpendapat bahwa segi kemukjizatan Al-Qur'an adalah keistimewaan-keistimewaan yang nampak dan keindahankeindahan yang terkandung dalam Al-Qur'an, baik dalam permulaan, tujuan maupun dalam menutup setiap surat. ${ }^{18}$

Imam al-Qurtubi dalam tafsirnya al-Jami'i Ahkamil Qur'an menyebutkan sepuluh segi kemukjizatan al-Quran, sementara al-Zarkani dalam kitabnya Manahilul Irfan mencatat empat belas segi kemukjizatan al-Quran. ${ }^{19}$ Perbedaan pendapat ulama diatas diketahui sesuai dengan kemampuan mereka masingmasing. Jadi bukan berbeda dalam menentukan batasan-batasan kemukjizatan Al-Qur'an, karena aspek-aspek kemukjizatan al-Quran tidak hanya terbatas pada aspek-aspek tertentu yang mereka sebutkan. ${ }^{20}$

Adapun aspek-aspek kemukjizatan Al-Qur'an adalah:

a. Susunan bahasanya yang indah, berbeda dengan susunan bahasa Arab.

b. Uslubnya (susunannya) yang menakjubkan, jauh berbeda dengan segala bentuk susunan bahasa Arab.

c. Keagungan yang tidak mungkin bagi makhluk untuk mendatangkan sesamanya.

d. Syariat yang sangat rinci dan sempurna melebihi setiap undang-undang buatan manusia.

e. Mengabarkan hal-hal ghaib yang tidak bisa diketahui kecuali dengan wahyu.

f. Tidak bertentangan dengan prinsip-prinsip ilmu pengetahuan.

g. Al-Quran memenuhi setiap janji dan ancaman yang dikabarkannya.

h. Luasnya ilmu-ilmu pengetahuan yang terkandung didalamnya.

i. Kesanggupannya dalam memenuhi segala kebutuhan manusia.

j. Berpengaruh terhadap hati para pengikutnya dan orang-orang yang memusuhinya. ${ }^{21}$

\section{Jenis Mukjizat Al-Qur'an}

\section{a. Mukjizat Dari Segi Bahasa}

Menghayati keindahan, ketelitian, serta kecematan pembahasan AlQur'an tidaklah mudah, terutama bagi bangsa kita yang pada umumnya kurang mempunyai apresiasi terhadap sastra Arab. Tetapi kemukjizatan Al-Qur'an justru dari segi kebahasaan, selain isi dan ilustrasi-ilustrasinya. Sejarah memperlihatkan bahwa Al-Qur'an diturunkan berdasarkan urutan kejadian dan

18 Muhammad Ali al-Shabuniy, Studi Ilmu al-Quran, terj. Aminuddin, (Bandung: Pustaka Setia, 1999), h. 137.

19 Muhammad Abdul 'Azim al-Zarkani, Manahilul Irfan fi Ulum al-Quran, Juz II, (Beirut: Dar al-Kutub al-'Ilmiyah, 1988), h. 355.

20 T.M. Hasbi Al-Shiddiqiey, Mu'djizat al-Qur'an, (Jakarta: Bulan Bintang, 1996), h. 33.

21 Muhammad Ali al-Shabuniy, Studi Ilmu al-Quran, terj. Aminuddin, (Bandung: Pustaka Setia, 1999), h. 138. 
tidak berdasarkan urutan ayat atau surah yang terlihat dalam mushaf baku. Bahkan ayat-ayat Al-Qur'an diturunkan secara spontan untuk menjawab persoalan-persoalan pelik yang dihadapi Nabi.

Para peneliti menemukan keajaiban yang luar biasa yang dimiliki AlQur'an, yang mustahil manusia mampu menandinginya. Abdul Razak Naufal ketika meneliti Al-Qur'an menemukan keseimbangan-keseimbangan dalam bilangan kata yang dipergunakan Al-Qur'an. Sementara Rasyad Khalifah menemukan konsistensi pemakaian jumlah huruf pembuka surah dalam surah yang bersangkutan. Sedang al-Rumani, al-Baqilani, dan Rasyid Ridha melihat sudut keindahan bahasa Al-Qur'an yang jauh melebihi keindahan sastra Arab.22

Setiap nabi yang diutus, senantiasa disesuaikan dengan keahlian masyarakatnya. Menurut Shihab, hal ini karena suatu keistimewaan baru dapat menjadi bukti bila aspek yang dikemukakan dapat dimengerti oleh mereka yang ditantang; dan bahwa bukti tersebut, akan semakin membungkamkan bila aspek tantangan dimaksud menyangkut sesuatu yang dinilai sebagai keunggulan yang ditantang. Sangat populer kita ketahui bahwa Al-Qur'an diturunkan dalam bahasa Arab karena masyarakat yang kepadanya pertama kali Al-Qur'an menggunakan bahasa Arab dalam berkomunikasi. Walaupun demikian, AlQur'an secara tegas menyatakan bahwa Al-Qur'an bukan semata-mata untuk orang-orang Arab, melainkan untuk seluruh alam.

Al-Qur'an pertama kali berinteraksi dengan masyarakat Arab pada masa Nabi Muhammad. Keahlian mereka adalah bahasa Arab dan sastra Arab. Di mana-mana terjadi musabakah (perlombaan) dalam menyusun syair atau khutbah, petuah, dan nasihat. Syair-syair yang dinilai indah, digantung di ka'bah, sebagai penghormatan kepada penggubahnya sekaligus untuk dinikmati oleh yang melihat atau membacanya. Penyair mendapat kedudukan yang istimewa dalam masyarakat Arab. Mereka dinilai sebagai pembela kaumnya. Dengan syair dan gubahan mereka reputasi suatu kaum atau seseorang dan juga - sebaliknya - dapat menjatuhkannya.

Karena alasan inilah, Al-Qur'an memiliki gaya bahasa yang khas yang tidak dapat ditiru oleh para sastrawan Arab, karena susunannya yang indah yang berlainan dengan setiap susunan dalam bahasa Arab. Mereka menyaksikan Al-Qur'an memakai bahasa dan lafal mereka, tetapi Al-Qur'an bukan puisi, prosa atau syair dan mereka tidak mempu membuat yang seperti itu (meniru AlQur'an).

Susunan gaya bahasa dalam Al-Qur'an tidak bisa disamakan oleh apapun, karena Al-Qur'an bukan susunan syair dan bukan pula susunan prosa, namun ketika Al-Qur'an dibaca maka ketika itu terasa dan terdengar mempunyai keunikan dalam irama dan ritmenya. Cendikiawaan Inggris, Marmaduke Pickthall dalam The Meaning of Glorious Quran, menulis: “Al-Qur'an

${ }_{22}$ M. Quraish Shihab, et. all., Sejarah dan Ulum Al-Qur"an, (Jakarta: Pusataka Firdaus, 2008), h. 114. 
mempunyai simfoni yang tidak ada taranya dimana setiap nada-nadanya bisa menggerakkan manusia untuk menangis dan bersuka-cita". ${ }^{23}$

Kajian mengenai Style Al-Qur`an, Shihabuddin menjelaskan dalam bukunya Stilistika Al-Qur`an, bahwa pemilihan huruf dalam Al-Qur'an dan penggabungannya antara konsonan dan vocal sangat serasi sehingga memudahkan dalam pengucapannya. Lebih lanjut-dengan mengutip AzZarqoni-keserasian tersebut adalah tata bunyi harakah, sukun,mad dan ghunnah (nasal). Dari paduan ini bacaan Al-Qur`an akan menyerupai suatu alunan musik atau irama lagu yang mengagumkan. Perpindahan dari satu nada ke nada yang lain sangat bervariasi sehingga warna musik yang ditimbulkanpun beragam.

Keserasian akhir ayat melebihi keindahan puisi, hal ini dikarenakan AlQur`an mempunyai purwakanti beragam sehingga tidak menjemukan. Misalnya dalam surat Al-Kahfi(18: 9-16) yang diakhiri vocal "a" dan diiringi konsonan yang berfariasi, sehingga tak aneh kalau mereka (masyarakat Arab) terenyuh dan mengira Muhammad berpuisi. Namun Walid Al-mughiroh membantah karena berbeda dengan kaidah-kaidah puisi yang ada, lalu ia mengira ucapan Muhammad adalah sihir karena mirip dengan keindahan bunyi sihir (mantra) yang prosais dan puitis. Sebagaimana pula dilontarkan oleh Montgomery Watt dalam bukunya "bell's Introduction to the Qoran" bahwa style Quran adalah Soothsayer Utterance (mantera tukang tenung), karena gaya itu sangat tipis dengan ganyanya tukang tenung, penyair dan orang gila. ${ }^{24}$

Kalimat-kalimat dalam Al-Qur`an mampu mengeluarkan sesuatu yang abstrak kepada fenomena yang konkrit sehingga dapat dirasakan ruh dinamikanya, termasuk menundukkan seluruh kata dalam suatu bahasa untuk setiap makna dan imajinasi yang digambarkannya. Kehalusan bahasa dan uslub Al-Qur`an yang menakjubkan terlihat dari balaghoh ${ }^{25}$ dan fasohah ${ }^{26}$ nya, baik yang konkrit maupun abstrak dalam mengekspresikan dan mengeksplorasi makna yang dituju sehingga dapat komunikatif antara Autor (Allah) dan penikmat (umat). ${ }^{27}$

Penulis ketika memperhatikan dengan seksama, bahwa dalam Al-Qur'an Allah hanya menuliskan satu profesi yang kemudian dijakikan judul surat, yakni Q.S. Asy-Syua'ara (26) yang berarti para penyair. Hal ini menunjukkan bahwa Al-Qur'an sendiri boleh jadi adalah kitab sastra. Ini juga menegaskan kepada kita bahwa Al-Qur'an yang merupakan karya sastra terbesar sepanjang zaman bisa

${ }^{23}$ M. Quraish Shihab, Mukjizat Al-Qur'an, Ditinjau dari Aspek Kebahasaan, Isyarat Ilmiah, dan Pemberitaan Ghaib (Bandung: Mizan, 2004), h. 123.

24 Shihabuddin Qulyubi, Stilistika Al-Quran, (Yogyakarta: Titan Ilahi Pers, 1997, h. 41.

25 Balaghah secara etimologi berarti "sampai ke puncak", sedangkan secara terminologi Balaghah adalah menyampaikan suatu gagasan melalui ungkapan yang benar, fasih, dan menyentuh jiwa serta sesuai denga tuntutan keadaan (kontekstual).

26 Menurut etimologi fashähah berarti jelas, terang dan gamblang. Secara terminologi fashāhah berarti lafaz yang jelas, terang maknanya, mudah dipahami dan sering dipergunakan para penyair dan penulis. Ia bernilai indah dan bagus ketika dibaca dan didengar.

27 Said Agil Hussein al-Munawwar. Al-Qur'an Membangun Tradisi Kesalehan Hakiki. Cet. ke-

2. (Jakarta: Ciputat Pres, 2002), h. 34. 
didekati dengan pendekatan sastrawi: sebuah pendekatan yang sejatinya sudah dirintis sejak zaman Nabi dan berkembang pada era klasik Islam. Dengan menggunakan piranti keilmuan kontemporer penulis telah meyakinkan pembaca bahwa pendekatan susastra bukan saja sah, bahkan salah satu pendekatan penting ketika hendak memahami kitab suci Al-Our'an.28

Allah swt. berfirman dalam Q.S. An-Nahl ayat 44 sebagai berikut:

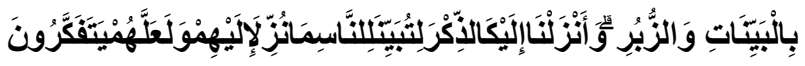

Artinya ;"Keterangan-keterangan (mukjizat) dan kitab-kitab. dan kami turunkan kepadamu Al Quran, agar kamu menerangkan pada umat manusia apa yang Telah diturunkan kepada mereka dan supaya mereka memikirkan."29

Al-Qur'an kitab suci umat Islam merupakan mukjizat yang kekal dan abadi. Ia adalah warisan nabi Muhammad saw. yang layak untuk diperebutkan dengan dipelajari dan diamalkan, guna mencapai kebagaiaan. ${ }^{30}$ Salah satu ciri gaya bicara Nabi Muhammad saw. adalah berkomunikasi dengan sejelasjelasnya. Beliau mengulang-ulang ucapan, seperti mengulang-ulang salam. Dengan begitu, lawan bicara dapat menangkap maksudnya, juga memahami tujuannya secara menyeluruh dengan lengkap, sehingga menakar dalam pikiran dan kesadaran. ${ }^{31}$

Al-Qur'an dapat menggetarkan hati pengikut dan penantangnya. Seseorang yang sangat memusuhi Al-Qur'an bisa berbalik di bawah lindungannya. Umar bin Khattab, Sa'ad bin Mu'az, dan Usaid bin Hudhair misalnya, mereka adalah orang-orang yang paling kejam terhadap kaum muslimin tetapi disebabkan mendengarkan beberapa ayat Al-Qur'an maka hatinya luluh dan masuk islam. Filosof Perancis mengatakan "Sesungguhnya Muhammad saw., membaca Al-Qur'an dengan khusyuk, sopan dan rendah hati, untuk menarik hati manusia agar beriman kepada Allah, dan hal ini melebihi pengaruh yang ditimbulkan semua mukjizat nabi-nabi terdahulu. ${ }^{32}$

\section{b. Mukjizat Dari Segi Pemberitaan Kisah}

\section{1) Pemberitaan Kisah Masa Lalu}

Salah satu kekuatan Al-Qur'an yang sekaligus menjadi mukjizatnya adalah pemaparan kisah-kisah lama yang sudah tidak hidup lagi dalam ceritacerita rakyat Arab saat itu, dan tidak mungkin akan ditemukan secara keseluruhan dalam kajian-kajian kesejarahan. Bahkan, Al-Qur'an memuat Surah

${ }_{28}$ M. Nur Kholis Setiawan, Al-Qur'an Kitab Sastra Terbesar (Sleman: Elsaq Press, 2007), h. 379.

${ }^{29}$ Kementrian Agama Republik Indonesia, Al-Qur'an dan Terjemahnya (Jakarta: Tehazed, 2010), h. 370.

30 Zainal Arifin Zakaria, Tafsir Inspirasi (Medan: Duta Azhar, 2015), h. 333

31 Wahbah Az-Zuhaili, Ensiklopedi Akhlak Muslim (Jakarta: Noura Books, 2014), h. 164

32 Muhammad Ali al-Shabuniy, Studi Ilmu al-Quran, terj. Aminuddin, (Bandung: Pustaka Setia, 1999), h. 220 
Al-Qashash (kisah-kisah) meskipun jika ditelaah tak hanya pada surah ini Allah mengabarkan kisah masa lalu, melainkan ada pada hampir setiap surah.

Diantara hal yang menarik dari Al-Qur`an adalah bahwa Al-Qur`an memuat beberapa cerita kaum-kaum terdahulu, hingga jauh ke hulu sejarah peradaban umat manusia yang tak mungkin buku sejarah manapun mampu mengcover secara akurat. Memang Al-Qur`an tidak memaparkan secara kronologis-histories, karena memang Al-Qur`an bukanlah buku sejarah. AlQur`an menggunakan sejarah purba tersebut hanya sebagai icon terhadap sebuah fenomena tertentu dengan maksud dan tujuan tertentu. Sehingga starting pointnya dalam memahami kisah-kisah yang terdapat dalam Al-Qur`an bukan dari dimensi histories, melainkan dari dimensi agama kisah merupaka metode Tuhan dalam rangka menyampaikan ajaran yang terkandung di dalamnya.

Rangkaian kisah-kisah dalam Al-Qur'an diungkapkan untuk menguraikan ajaran-ajaran keagamaan, serta menggambarkan akibat-akibat bagi yang menentangnya .Ini merupakan salah satu keistimewaan dan kekuatan AlQur'an. Kisah-kisah tersebut bukanlah sesuatu yang fiktif, tetapi dapat diyakini sebagai sesuatu yang pernah terjadi di muka bumi. ${ }^{33}$

\section{2) Pemberitaan Peristiwa Yang Akan Datang}

Di samping mengangkat peristiwa-peristiwa silam lewatrangkaian kisahkisah, Al-Qur'an juga mengungkapkan perstiwa-peristiwa yang akan terjadi, baik di dunia maupun di akhirat nanti.Peristiwa-peristiwa yang digambarkan Al-Qur'anakan terjadi, danbeberapa telah terbukti dalam sejarah.

Adanya kisah-kisah misterius dalam Al-Qur`an, menempatkannya sebagai ajaran kehidupan yang mencakup total tata nilai mulai hulu peradaban umat manusia hingga hilirnya. Bahwa peristiwa-peristiwa tersebut sengaja dihadirkan oleh Tuhan agar manusia mampu menjadikannya sebagai 'ibrah (pelajaran) kehidupan. Ia merupakan sebuah metode yang dipilih Tuhan untuk menuangkan nilai yang terkandung didalamnya.

Allah swt. berfirman pada Q.S. An-Nisa ayat 82 untuk memberitahu bahwa Al-Qur'an memanglah diturunkan oleh Allah swt. sebagai berikut :

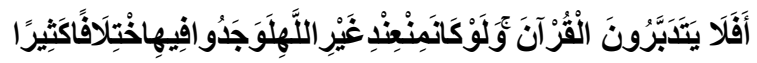

Artinya;"Maka apakah mereka tidak memperhatikan Al Quran? kalau kiranya Al Quran itu bukan dari sisi Allah, tentulah mereka mendapat pertentangan yang banyak di dalamnya." 34

\section{c. Mukjizat Dari Segi Isyarat Keilmuan dan Ilmiah}

Selain memiliki kekuatan dalam segi kebahasaan dan pemberitaan, AlQur'an juga memperlihatkan keistimewaannya melalui ilustrasi-ilustrasi

33 Subhi As-Shalih, Membahas Ilmu-ilmu Al-Qur'an, (Jakarta: Pustaka Firdaus, 2008), h. 448

34 Kementrian Agama Republik Indonesia, Al-Qur'an dan Terjemahnya (Jakarta: Tehazed, 2010), h. 118. 
ajarannya yang memberi isyarat kearah pengembangan ilmu pengetahuan dan teknologi. Ilustrasi ajaran-ajarannya menyoroti banyak hal yang ada dalam kehidupan alamini, baik mengenai proses terjadinya alam, mekanisme kehidupan makhluk-makhluk-Nya termasuk manusia, hewan dan tumbuhtumbuhan. ${ }^{35}$ Yang dimaksud dengan kemukjizatan saintifik adalah bahwa AlQur'an telah memuat isyarat kebenaran ilmiah yang belum diketahui masyarakat ketika turunnya Al-Qur'an. ${ }^{36}$

Al-Qur'an mendorong perkembangan ilmu pengetahuan. Al-Qur'an mendorong umat Islam untuk memerdekakan akal dari belenggu keraguan, melepas belenggu-belenggu berfikir, dan mendorong untuk mengamati fenomena alam atau lebih dikenaldengan ayat-ayat kauniyah. ${ }^{37}$ Pembahasan mukjizat ilmiah dari ayat-ayat kauniyah (yang menyebutkan tentang fenomena alam) dalam Al-Qur'an sangat berkaitan dengan gejala-gejala alam dan keterangan hadis nabiterhadap ilmu ini, sehingga termasuk ke dalam bidang ilmu tafsir yang lebih dikenal dengan tafsir ilmi. ${ }^{38}$

Mengenai boleh tidaknya tafsir ilmi digunakan dalam penafsiran AlQur'an berbeda pendapat ada yang memperbolehkan dan ada yang tidak memperbolehkan. Terlepas dari hal itu, yang jelas bahwa Al-Qur'an telah mengisyaratkan atau mengabarkan kita tentang fakta-fakta ilmiah yang kelak ditemukan dan dibuktikan oleh eksperimen sains umat manusia.

Dari hasil penelitian, pengamatan dan kesimpulan para ilmuwan Muslim, yang secara serius melakukan kajian terhadap dimensi keilmuan dalam AlQur'an, terlihat bahwa Al-Qur'an telah mengisyaratkan pertumbuhan berbagai bidang ilmu, baik ilmu-ilmu keamanan maupun sosial kemasyarakatan. Penelitian dan kajian tentang isyarat-isyarat Al-Qur'an terhadap ilmu pengetahuan masih terus dilakukan para ilmuwan Muslim, untuk menjadikan Al-Qur'an sebagai salah satu bahan informasi awal atau sumber inspirasi untuk mengembangkan kajian-kajian sains, baik ilmu murni maupun terapan.

Dari sekian banyak ayat-ayat yang mengisyaratkan ilmu pengetahuan, para ilmuwan telah mampu merekonstruksi ayat sehingga terlihat gagasan konsepsional yang dikemukakannya dalam bidang-bidangilmu tertentu. Di antara cabang-cabang ilmu yang memperoleh perhatian serius dari Al-Qur'an dan terekonstruksi secara baik olehpara saintis adalah fisika, biologi, astronomi, kimia, dan geologi. Sedang lainnya masih terus dalam proses kajian dan penelaahan dengan bantuan ilmu-ilmu empirik hasil rumusan para ilmuwan. ${ }^{39}$

${ }^{35}$ Muhammad Ismail Ibrahim, Al-Qur'an wa I'jazuhu al-'Ilmi, (Kairo: Dar al-Fikr, t.t.),

h. 17.

36 Zaghlul An-Najjar, Min Ayat Al-I'jaz Al-Ilmi, (Kairo: Maktabah Asy-Syuruq AdDauliyah, 2008), h. 36.

37 Rosihon Anwar, Ilmu Tafsir, (Bandung: CV. Pustaka Setia, 2004), h. 170.

38 Abdul Majid al-Zindani, Mukjizat Al-Qur'an dan As-Sunnah Mengenai IPTEK, (Jakarta: Gema Insani Press, 1997), h. 26.

${ }^{39}$ Ahmad Baiquni, Islam dan Ilmu Pengetahuan Modern, (Bandung: Pustaka, 1983), h. 17. 
Berikut ini adalah sedikit contoh ayat dalam Al-Qur'an yang menunjukkan isyarat ilmiah, antara lain:

a. Cahaya matahari bersumber dari dirinya dan cahaya bulan merupakan pantulan. Terdapat dalam Q.S. Yunus: 5.

b. Kurangnya oksigen pada ketinggian dapat menyesakan napas, hal ini terdapat pada surat Al-An'am: 25

c. Perbedaan sidik jari manusia. Terdapat dalam surat Al-Qiyamah: 4

d. Aroma/bau manusia berbeda-beda. Terdapat dalam surat Yusuf: 94

e. Masa penyusuan yang tepat dan kehamilan minimal. Terdapat dalam surat Al-Baqarah: 233

f. Adanya nurani (super ego) dan bawah sadar manusia. Terdapat dalam surat Al-Qiyamah: 14

\section{Aspek Kemukjizatan Syariat}

Sudah banyak ditemukan dalam sejarah kehidupan manusia tentang upaya-upaya yang dilakukan untuk mewujudkan kehidupan yang damai dan adil, tapi sering kali upaya itu tidak sampai pada tujuan yang diinginkan. Sehingga kehidupan harmonis yang diharapkan tidak pernah terealisasi. Islam datang membawa keadilan, membawa syariat untuk menciptakan kenyaman dalam hidup bermasyarakat. Dalam pembentukan masyarakat yang baik tidak dapat terlepas dari upaya awal untuk membentuk dan mendidik kepribadian yang baik pula.

Sehingga bila setiap individu yang menjadi anggota masyarakt telah baik, secara tidak langsung kebaikan itu akan memunculkan kebaikan koletif. AlQur`an menuntun setiap muslim untuk memegang teguh ketauhidan yang merupakan landasan pokok dalam beramal. Ketauhidan ini akan menjauhkan dirinya dari keyakinan terhadap khurafat, keraguan, dan dari menjadi budak nafsu serta penyembahan terhadap syahwat. Sehingga ia menjadi seorang hamba yang bersih keyakinannya pada Allah. Yang hanya patuh dan tunduk pada Tuhan yang satu. Tidak butuh kepada selain-Nya. Tuhan yang memiliki kesempurnaan. Yang darinya datang segala kebaikan untuk segenap makhlukNya.

Dialah tuhan yang satu, pencipta yang satu, yang maha kuasa atas segala sesuatu. Apabila akidah seorang muslim telah lurus dan benar maka hendaklah ia mengambil konsep hidupnya sesuai dengan tuntunan syariat yang dinyatakan dalam Al-Qur`an. Setiap ibadah fardhu yang ditujukan untuk kemaslahatan individu akan tetapi pada waktu yang bersamaan ia juga bertujuan untuk kemaslahatan hidup bersama. Ibadah shalat bertujuan untuk mencegah seseorang dari berperilaku keji dan mungkar (Al-Angkabut : 45). Dengan terlaksananya shalat dengan baik, akan terpancarlah pada diri seorang muslim sikap yang baik pula, tenang dan membawa kedamaian pada orang yang ada disekitarnya. 
Zakat membuang dari diri sikap bakhil, kecintaan pada dunia, ketamakan pada harta. Disisi lain zakat akan menjadi sarana saling tolong menolong antara yang kaya pada yang miskin. Dimana yang kaya memberikan sebahagian dari hartanya untuk membantu orang-orang yang membutuhkan dan berhak. Ibadah haji adalah sarana untuk latihan diri menempuh kesulitan. Pada saat haji semua manusia akan berkumpul pada satu tempat, semuanya dengan pakaian yang sama, dan tidak ada yang membedakan mereka kecuali ketakwaan. Sedangkan puasa melatih seseorang untuk mengendalikan hawa nafsunya. Ketika berpuasa seseorang akan dilatih untuk menahan amarahnya.

Disamping akan terlatih kejujurannya. Semua ibadah diatas bila dilaksanakan dengan sebagaimana mestinya akan melahirkan dalam diri setiap muslim pribadi yang soleh, Al-Qur`an juga mengajarkan untuk berlaku sabar, jujur, bersikap adil, ihsan, memaafkan orang lain dan sikap-sikap mulia lainnya. Al-Quran juga telah menetapkan perlindungan terhadap dharuriyah alkhomsahatau (lima kebutuhan primer) bagi kehidupan manusia yaitu: agama, jiwa, kehormatan,harta benda,dan akal. Lalu menerapkan hukuman-hukuman yang tegas pada setiap poin-poinya sehingga dikenal dalam fiqih islam hukum jinayat dan hudud.

Al-Quran juga menetapkan hukum terntang hubungan internasional antara kaum muslimin dengan negara tetangga atau dengan merika yang mengadakan perjanjian damai (mu'ahad). Juga kekuasaan legislatif dalam sistem pemerintahan islam diatur dalam al-Quran. Ringkasnya al-quran meupakan Dustur Tasyri'i (sistem perundang-undangan) paripurna yang membangun kehidupan manusia diatas dasar konsep yang paling tinggi dan mulia. Kemukjizatan Tasyri'inya ini tidak bisa dipisahkan dari kemukjizatan ilmiah dan kemukjizatan bahasanya. Ketiganya akan senantiasa eksis bersama tak seorangpun dapat mengingkari bahwa al-Quran memiliki kemukjizatan sebagai bukti kekuasaan Allah.

\section{Kearah Baru dalam Memahami I'jaz}

Banyak orang terjebak dalam kesalahan ketika mereka menginginkan agar Al-quran mengandung segala teori ilmiah. Setiap lahir teori baru mereka mencarikan untuknya kemungkinannya dalam ayat, lalu ayat ini mereka takwilkan sesuai dengan teori ilmiah tersebut. Kemukjizatan ilmiah Alquran bukanlah terletak pada pencakupannya akan teori-teori ilmiah yang selalu baru dan berubah serta merupakan hasil usaha manusia dalam penelitian dan pengamatan. Tetapi terletak pada dorongannya untuk berfikir dan menggunakan akal. Alquran mendorong manusia agar memperhatikan dan memikirkan alam.Ia tidak membatasi aktivitas dan kreatifitas akal dalam 
memikirkan alam semesta, atau menghalanginya dari penambahan ilmu pengetahuan yang dapat dicapainya. ${ }^{40}$

Alquran menjadikan pemikiran yang lurus dan perhatian yang tepat terhadap alam dan segala apa yang ada di dalamnya sebagai sarana terbesar untuk beriman kepada Allah. Alquran mendorong manusia untuk melakukan aktivitas intelektual sebagaimana dijabarkan dalam ayat-ayatnya. Pertama, Ia mendorong kaum Muslimin agar memikirkan makhluk makhluk Allah yang ada di langit dan di bumi, seperti dalam firman Allah pada (Q.S. Ali Imran : 190191):"Sesunggguhnya dalam penciptaan langit dan bumi, dan silih bergantinya malam dan siang terdapat tanda-tanda bagi orang-orang yang berakal, (yaitu) mereka yang mengingat Allah sambil berdiri atau duduk atau dalam keadaan berbaring dan mereka memikirkan tentang penciptaan langit dan bumi (saya bersaksi): Ya Tuhan kami, tiadalah Engkau menciptakan ini dengan sia-sia. Maha suci Engkau, maka peliharalah kami dari siksa neraka."

Kedua, Alquran mendorong umat Islam agar memikirkan dirinya sendiri, bumi yang ditempatinya dan alam yang mengitarinya, seperti dalam firman Allahpada Q.S. ar-Rum: 8:"Dan mengapakah mereka tidak memikirkan tentang (kejadian) dirimereka? Allah tidak menjadikan langit dan bumi dan apa yang ada di antara keduanya melainkan dengan (tujuan) yang benar dan waktu yang ditentukan.

Ketiga, Alquran membangkitkan pada diri setiap Muslim kesadaran ilmiah untuk memahami dan melakukan perbandingan, seperti dalam firmanAllah (Q.S. al-Baqarah :219):“Demikianlah Allah menerangkan ayat-ayatNya kepadamu supayakamu berpikir." "Dan perumpamaan-perumpamaan itu Kami buat untuk manusia supaya mereka berpikir." (Q.S. al-Hasyr : 21).

Ketiga tuntunan di atas menghimbau manusia untuk tidak hanya membaca Alquran dengan hanya sekedar membaca, akan tetapi sekaligus mengajak manusia menerapkan bacaan dan kandungan Alquran dalam kehidupan, sebagaimana pesan M. Quraish Shihab yaitu membumikan Alquran.

\section{Simpulan}

Jurnal ini menyimpulkan bahwa kemukjizatan Al-Qur'an tidak mungkin bisa tertandingi. Hal ini terwujud dalam aspek keindahan bahasa, kisah yang terkandung di dalamnya, selain tauhid, aturan syariat, dan sebagainya, serta informasi ilmiah yang luar biasa lengkapnya jika ditelaah secara mendalam. Untuk mengapresiasi kemukjizatan Al-Qur'an ini, hendaknya setiap umat Islam memenuhi hak Al-Qur'an yaitu dengan membaca, menghafal, menganalisa serta diaplikasikan dalam kehidupan sehari-hari sebagai petunjuk bagi orang yang bertakwa. Al-qur'an juga mendorong manusia untuk melakukan aktivitas intelektual agar memikirkan makhluk-makhluk Allah yang ada di langit dan di

40 Manna Khalil al-Qaththan, Studi Ilmu-ilmu al-Alquran, (Bogor: Pustaka Litera Antar Nusa, 2001), h. 386. 
bumi. Alquran juga membangkitkan pada diri setiap Muslim kesadaran ilmiah untuk memahami dan melakukan perbandingan serta melakukan pemharuan.

\section{Referensi}

Abdurrahman, Aisyah, Al-I'jaz Al-Bayani lil Quran. Kairo: Darul Maarif, t.th.

Ahmad, Yusuf Al-Hajj. Mukjizat Al-Qur'an yang Tak Terbantahkan. Solo: Aqwam, 2016.

Ahmad Fuad Pasya, Dimensi Sains AI-Qur'an, cet.I, Solo: PT.TigaSerangkai Pustaka Mandiri, 2004.

Alimi, Ibnu Ahmad. Menyingkap Rahasia Mukjizat Al-Qur'an. Surabaya: Mashur, 2004.

Al-Munawwar, Said Agil Husain. I'jaz Al-Qur'an dan Metodologi Tafsir. Semarang: Dimas, 1994.

------ Al-Qur'an Membangun Tradisi Kesalehan Hakiki. Cet. ke-2. Jakarta: Ciputat Pres, 2002.

al-Zindani, Abdul Majid. Mukjizat Al-Qur'an dan As-Sunnah Mengenai IPTEK. Jakarta: Gema Insani Press, 1997.

Anwar, Rosihon. Ilmu Tafsir. Bandung: CV. Pustaka Setia, 2004.

An-Najjar, Zaghlul. Min Ayat Al-I'jaz Al-Ilmi. Kairo: Maktabah Asy-Syuruq AdDauliyah, 2008.

As-Shabuniy, Muhammad Ali. Studi Ilmu al-Quran, terj. Aminuddin. Bandung: Pustaka Setia, 1999.

As-Shalih, Subhi. Membahas Ilmu-ilmu Al-Qur'an. Jakarta: Pustaka Firdaus, 2008.

As-Shiddiqiey, T.M. Hasbi. Mu'djizat al-Qur'an. Jakarta: Bulan Bintang, 1996.

Az-Zarkani, Muhammad Abdul 'Azim Manahilul Irfan fi Ulum al-Quran, Juz II. Beirut: Dar al-Kutub al-'Ilmiyah, 1988.

Az-Zarqani, Muhammad, Manahil al-Irfan fi Ulum al-Alquran, Jilid. 1,tahqiq: Fawwaz Ahmad Zamarli, Beirut: Dar al-Kutub al-Arabi, 1415 H/1995 M.

Az-Zuhaili, Wahbah. Ensiklopedi Akhlak Muslim. Jakarta: Noura Books, 2014.

Baiquni, Ahmad. Islam dan Ilmu Pengetahuan Modern. Bandung: Pustaka, 1983.

Ibrahim, Muhammad Ismail. Al-Qur'an wa I'jazuhu al-'Ilmi. Kairo: Dar al-Fikr, t.t.

Kementrian Agama Republik Indonesia, Al-Qur'an dan Terjemahnya. Jakarta: Tehazed, 2010.

Khallaf, Abdul Wahab. Ilmu Ushul Figh, cet. 8, terj. Noer Iskandar al-Barsany dan Moh. Tolchah Mansoer. Kairo: Dar al-'Ilm:1978.

Manna Khalil al-Qaththan, Studi Ilmu-ilmu al-Alquran,Bogor: Pustaka Litera AntarNusa, 2001.

Manzur, Ibn. Lisan al-Arab Jilid II. Beirut: Dar Sodir, t.t.

Setiawan, M. Nur Kholis. Al-Qur'an Kitab Sastra Terbesar. Sleman: Elsaq Press, 2007. 
Shihab, M. Quraish. et. all., Sejarah dan Ulum Al-Qur"an. Jakarta: Pusataka Firdaus, 2008.

----- Mukjizat Al-Qur'an, Ditinjau dari Aspek Kebahasaan, Isyarat Ilmiah, dan Pemberitaan Ghaib. Bandung: Mizan, 2004.

Wawasan AL-Qur'an. Bandung: Mizan, 1996.

Syahin, Abdul Shabur. Saat Al-Qur'an Butuh Pembelaan. Jakarta: Erlangga, 2014.

Tim Penyusun, Ensiklopedi Hukum Islam Jilid 4. Jakarta: PT. Bachtiar Baru Van Houve, 1997.

Qardhawi, Yusuf. Al-Qur'an Berbicara tentang Akal dan Ilmu Pengetahuan. Jakarta: Gema Insani Press, 1998.

Qulyubi, Shihabuddin. Stilistika Al-Quran. Yogyakarta: Titan Ilahi Pers, 1997.

Zakaria, Zainal Arifin. Tafsir Inspirasi. Medan: Duta Azhar, 2015. 